\title{
RANCANG BANGUN APLIKASI PENDATAAN PELANGGARAN SISWA SMP NEGERI 229 JAKARTA BERBASIS JAVA
}

\author{
Farhannuari Bani Romadhan ${ }^{1}$, Dwi Yulistyanti ${ }^{2}$, Syamsiah $^{3}$ \\ Program Studi Teknik Informatika, Fakultas Teknik dan Ilmu Komputer, \\ Universitas Indraprasta PGRI \\ Jalan Raya Tengah No 80, Kelurahan Gedong, Pasar Rebo, Jakarta Timur \\ nuari.br@gmail.com ${ }^{1}$, unindra.dwiyulist@gmail.com ${ }^{2}$, syamsiahunindra@yahoo.co.id ${ }^{3}$
}

\begin{abstract}
Abstrak
Didalam dunia pendidikan tingkat SMP, siswa atau pelajar merupakan tahap yang sudah dikategorikan pada usia remaja dan sedang dalam persiapan mencari jati diri. Oleh karena itu, banyak terjadi kenakalankenakalan remaja didalam dunia pendidikan tingkat SMP. Dibuatnya aplikasi pendataan pelanggaran siswa ini ialah dikarenakan bagian bimbingan konseling masih menggunakan buku besar untuk pendataan siswa yang melanggar ketentuan sekolah mengakibatkan akumulasi poin pelanggaran tidak berjalan dengan vaik, hal ini dapat mempengaruhi tindakan yang harus dilakukan oleh bagian bimbingan konseling SMP Negeri 229 Jakarta untuk menangani pelanggaran yang dilakukan oleh siswa. Dibuatlah aplikasi sistem informasi dengan tujuan pengembangan dalam hal Pendataan Pelanggaran pada bagian bimbingan konseling SMP 229 Jakarta. Pada hal ini bimbingan konseling memerlukan suatu sistem dimana bisa mengakumulasi point yang pernah dilakukan oleh siswa. Dengan dibuatnya aplikasi Pendataan Pelanggaran siswa berbasis java ini bimbingan konseling dapat mengetahui informasi poin yang sudah didapat siswa serta mengetahui pelanggaran apa saja yang pernah dilakukan oleh siswa. Sehingga tidak membutuhkan waktu yang cukup lama dalam penanganan siswa yang melakukan pelanggaran.
\end{abstract}

Kata Kunci: Rancang Bangun, Pendataan Pelanggaran, Java

\begin{abstract}
In the world of junior high school education, students or students are a stage that has been categorized as adolescence and is in preparation for identity. Therefore, there are many juvenile delinquencies in the world of junior high school education. The making of this application for data collection of student violations is because the counseling guidance section still uses ledger for data collection of students who violate school provisions resulting in the accumulation of violation points does not go well, this can affect the actions that must be done by the counseling guidance section of SMP Negeri 229 Jakarta to deal with violations committed by students. The application of information system with the aim of development in terms of data collection violations in the counseling guidance section of SMP Negeri 229 Jakarta. in this case counseling guidance requires a system where students can accumulate points. With the making of this java-based student violation data collection application counseling guidance can know the information points that have been obtained by students and know what violations have been committed by students. So, it does not take long enough in the handler of students who commit violations.
\end{abstract}

Keywords: Building Design, Violation Data Collection, Java

\section{PENDAHULUAN}

Aplikasi merupakan suatu sistem yanga dibuat oleh manusia terdiri atas komponen-komponen dalam satu organisasi untuk mencapai suatu tujuan yaitu untuk menyajikan informasi. Menurut (Sutabri, 2012) Aplikasi adalah alat terapan yang difungsikan secara khusus dan terpadu sesuai kemampuan yang dimilikinya. Aplikasi teknologi informasi di dunia pendidikan bertujuan untuk mengelola proses data guna membantu proses belajar mengajar maupun dalam administrasi pendidikan. Tujuan lain adalah memfasilitasi dunia pendidikan dalam meningkatkan kinerja dengan membuat dan menggunakan sebuah aplikasi yang mampu memberikan informasi yang dibutuhkan. Aplikasi pendataan pelanggaran siswa di SMP Negeri 229 Jakarta memberikan peranan penting dalam pembangunan akhlak pada siswa di sekolah.

Di dalam dunia pendidikan tingkat SMP, siswa atau pelajar merupakan tahap yang sudah dikategorikan pada usia remaja yang sedang dalam persiapan mencari jati diri. Oleh karena itu 
pantas bila cukup banyak terjadi kenakalan-kenakalan remaja didalam dunia pendidikan tingkat SMP. Untuk mengatasi manajemen data siswa khususnya bagi siswa yang melakukan pelanggaran. Pengelolahan data siswa, khususnya data pelanggaran merupakan salah satu bentuk pelayanan administrasi sekolah. Selama ini pengelolahan data siswa, khususnya data pelanggaran siswa di SMP Negeri 229 Jakarta masih menggunakan buku besar, sehingga dalam pengarsipan banyak data yang tercecer, rusak hingga hilangnya data mengakibatkan perlunya waktu lebih untuk pembukuan data pelanggaran siswa dalam sebuah arsip sekolah Pengarsipan adalah metode atau cara yang dipergunakan dalam penyimpanan dan penemuan kembali arsip/ dokumen (Pascapraharastyan et al., 2014).

\section{PENELITIAN RELEVAN}

Dalam rangka mendapatkan hasil penelitian yang baik, selain melakukan penelitian secara langsung peneliti juga melakukan kajian pustaka. Dari hasil penelitian yang telah dilakukan. Beberapa hasil acuan yang menjadi acuan adalah:

Penelitian dari Ahmad Taufiq Hidayatullah \& Fajar Perdana, tahun 2017 berjudul "Pengembangan sistem informasi bimbingan konseling siswa SMP Negeri 1 Panarukan". Menciptakan pembentukan pribadi siswa yang berakhlak dengan pemanfaatan sistem informasi yang mengatur poin pelanggaran untuk mendapatkan penilai akhlak pada siswa dan perlunya pengembangan sistem informasi yang mempunyai manfaat untuk terciptanya beberapa ruang lingkup yang mencakup pencatata poin pelanggaran yang dapat terakumulasi dengan baik.

Penelitian dari Muhammad Amzulian Rivaldy dan Lusi Fajarita, tahun 2018 berjudul "Rancang Bangun Sistem Informasi Poin Pelanggaran dan Bimbingan Konseling Pada SMA Az-Zamir". Membuat Sistem Informasi Poin Pelanggaran Siswa dan Bimbingan Konseling pada SMA Islam Az-Zamir dengan melakukan analisa terhadap kekurangan yang perlu diperbarui dari sistem poin pelanggaran siswa yang lama. Tersedia modul entry jenis pelangaran yang dapat membantu Guru BK dalam menangani siswa yang bermasalah serta meminimalisir terjadinya kesalagan pada proses perhitungan dan akumulasi poin pelanggaran.

Penelitian Rizki Wahyudi dan Aprilita Dwi Aristantia, tahun 2017 berjudul "Aplikasi Pengolahan Data Pelanggaran Siswa Pada SMK Yayasan Pendidikan Teknologi I Purbalingga Terintegrasi Dengan SMS Gateway". Penelitian ini bertujuan untuk mempermudah penanganan ketidakdisiplinan siswa dalam lingkungan sekolah dengan membangun aplikasi yang mempermudah perhitungan point pelanggaran tata tertib siswa sehingga pihak sekolah dapat melakukan tindakan dan kebijakan-kebijakan yang berkaitan dengan peningkatan kepribadian siswa serta dengan di integrasikannya aplikasi dengan sms gateway yang secara otomatis mengirimkan laporan tentang ketidakdisiplinan siswa langsung kepada wali murid. Data poin pelanggaran siswa di ambil dari SMK YPT 1 Purbalingga. Jumlah point kesalahan yang dihitung kemudian ditindak lanjuti dalam berbagai tingkatan, mulai dari peringatan, panggilan disertai membuat surat perjanjian, sampai pada tingkat yang paling tinggi dengan bobot/jumlah point kesalahan paling besar dikembalikan kepada wali murid.

Penelitian Petrisisan W Sudarmadji dan Andreas Bani, tahun 2017 berjudul "Pembuatan Aplikasi Pendataan Pada SMA Negeri I Amfoang Utara Kabupaten Kupang". Dalam proses pendataan tersebut masih menggunakan Microsoft Office Excel dan buku-bukubesar. Dengan cara ini, guru maupun pegawai harus menyusun tabel berisi semua data siswa, data guru, data nilai, data kelas, data mata pelajaran, dan pendataan tersebut seringkali timbul permasalahan yang menghabiskan banyak kertas dan diperlukan waktu yang sangat banyak. Dengan pertimbangan dan permasalahan di atas, oleh karena itu penyusun memutuskan untuk membuat Aplikasi Pendataan Pada SMA Negeri 1 Amfoang Utara, yang membahas atau mencakup data siswa, data guru, data nilai, data kelas, dan data mata pelajaran. Hal ini sangat memberikan kinerja yang lebih bagi sekolah, para guru dan pegawai.

Penelitian Sri Ipnuwati, tahun 2014 berjudul "Sistem Pendukung Keputusan Pemberian Sanksi Pelanggaran Kedisiplinan Siswa Pada SMK PGRI I Kendodonng". Dalam hal ini para siswa yang melanggar peraturan akan diberikan sanksi atau point sehingga memberikan output nilai intensitas prioritas yang menghasilkan suatu sistem yang memberikan penilaian terhadap siswa. Sistem pendukung keputusan ini membantu melakukan penilaian setiap Siswa, melakukan perubahan kriteria,dan perubahan nilai point. Hal ini berguna untuk memudahkan pengambil keputusan yang 
terkait dengan masalah Kedisiplinan. Aplikasi yang dibuat dapat digunakan untuk membantu dalam pengolahan data pelanggaran tata tertib sekolah khususnya pelanggaran siswa pada SMK PGRI I Kedondong Kecamatan Kedondong Kabupaten Pesawaran Provinsi Lampung, dan dapat mempermudah dan mempercepat pengolahan data pelanggaran tata tertib siswa. Dengan adanya sistem pendukung keputusan ini diharapkan pejabat terkait tidak akan kesulitan dalam menentukan siswa yang melakukan pelanggaran (ketidakdisiplinan) sekolah dan bagi siswa yang melanggar tatatertib akan mendapat sanksi atau point.

Penulisan yang dilakukan berlandasan dari penelitian relevan sebebelumnya, maka dikembangkanlah sistem pendataan pelanggaran yang lebih efektif dalam menangani permasalahan pelanggaran siswa. Aplikasi Pendataan Pelanggaran Siswa di SMP Negeri 229 Jakarta saat ini lebih dinamis dalam penghitungan poin pelanggaran siswa juga lebih mudah dalam penggunaannya dan aplikasi ini mempunyai kelebihan dalam hal laporan pelanggaran persiswa, laporan yang dibuat bukan hanya untuk pihak sekolah yang melihatnya melainkan laporan bisa dilihat orang tua siswa dengan dikirimkan ke email orang tua siswa melalui aplikasi ini.

\section{METODE PENELITIAN}

Dalam penelitian ini peneliti menggunakan penelitian Research and Development (R\&D). Menurut (Sugiyono, 2014) metode penelitian Research and Development yang selanjutnya akan disingkat menjadi R\&D adalah metode penelitian yang digunakan untuk menghasilkan produk tertentu. Metode yang digunakan yaitu metode kualitatif wawancara dan penelaahan dokumen.

Menggunakan Observasi Menurut (Syah, 2010) mengemukakan beberapa untuk observasi, yaitu: Observasi partisipasi, observasi tidak terstruktur, dan observasi kelompok. Pengertian Observasi atau cara-cara yang menganalisis dan mengadakan pencatatan secara sistematis mengenai tingkah laku dengan melihat atau mengamati individual atau kelompok secara langsung.

Melakukan Wawancara Suatu cara pengumpulan data yang digunakan untuk memperoleh informasi langsung dari sumbernya. Wawancara dilakukan secara lisan dalam pertemuan tatap muka secara individu.

Metode pengembangan sistem yang digunakan dalam penenelitian ini adalah menggunakan metode Waterfall, menurut (Pressman, 2015) waterfall adalah model klasik bersifat sistematis, berurutan dalam membangun software. Sebenarnya nama model ini adalah "Linier Sequential Model". Model ini dapat disebut juga dengan nama"classic life cycle" atau waterfall.

\section{HASIL DAN PEMBAHASAN}

Dengan melihat masalah yang ada, kondisi bimbingan konseling SMP Negeri 229 Jakarta Barat belum menggunakan teknologi informasi dan masih menerapkan sistem dengan pencatatan pelanggaran di buku besar, terlihat bahwa bimbingan konseling yang ada di SMP Negeri 229 Jakarta Barat kesulitan dalam mengelola mendata dan mengakumulasi poin yang pernah dilakukan oleh siswa, sehingga pendataan dan akumulasi poin pelanggaran tidak efekttif. Penerapan aplikasi pendataan pelanggaran siswa di SMP Negeri 229 Jakarta Barat berbasis java dan Berikut ini merupakan penggambaran tentang metode yang digunakan pada rancang bangun aplikasi pendataan pelanggaran siswa SMP Negeri 229 Jakarta.

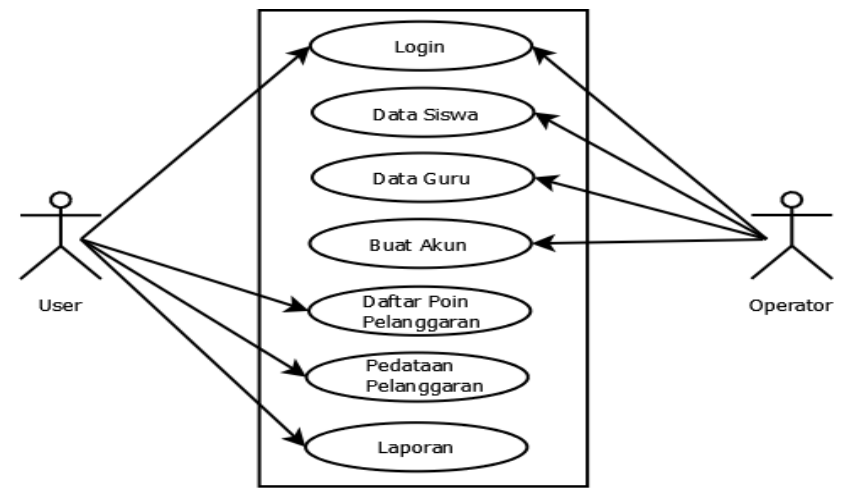

Gambar 1. Use Case Diagram 
Gambar diatas merupakan Use Case Diagram yang menampilkan alur pemakaian aplikasi dan mendeskripsikan tampilan halaman user dan operator

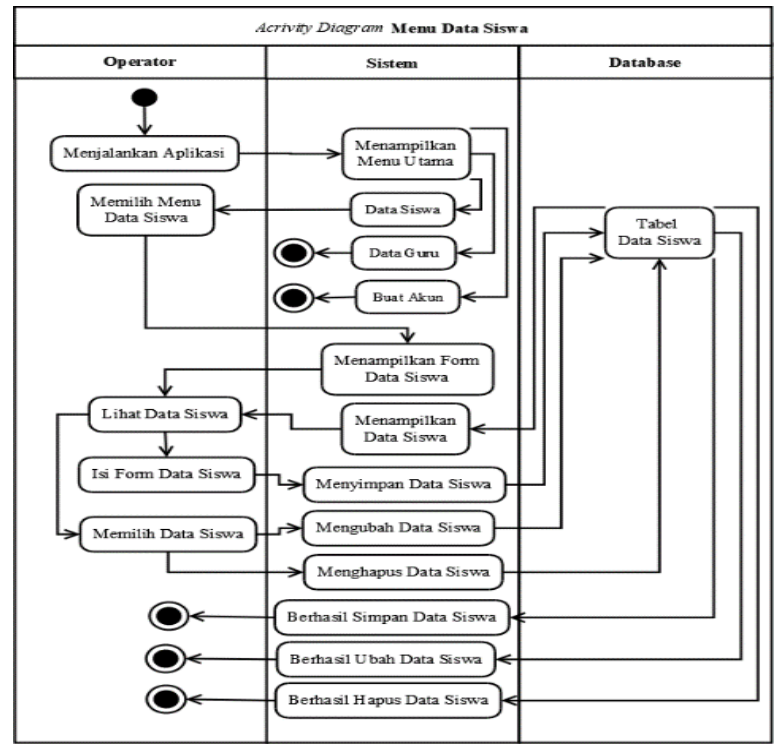

Gambar 2. Activity Diagram

Gambar diatas adalah activity diagram yang menggambarkan tahapan proses dan jalur aktivitas pada sistem yang akan berjalan didalam sebuah aplikasi.

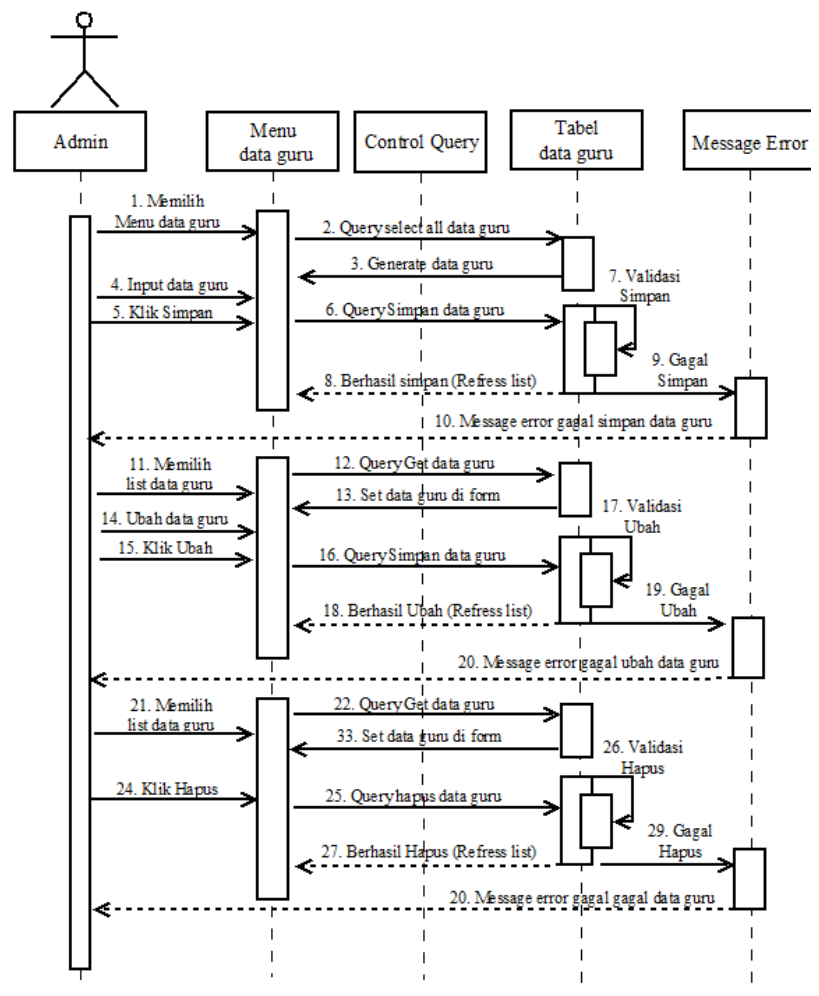

Gambar 3. Sequence Diagram

Gambar diatas adalah Sequence Diagram yang merepresentasi dari interaksi-interaksi objek yang berjalan pada sistem. 


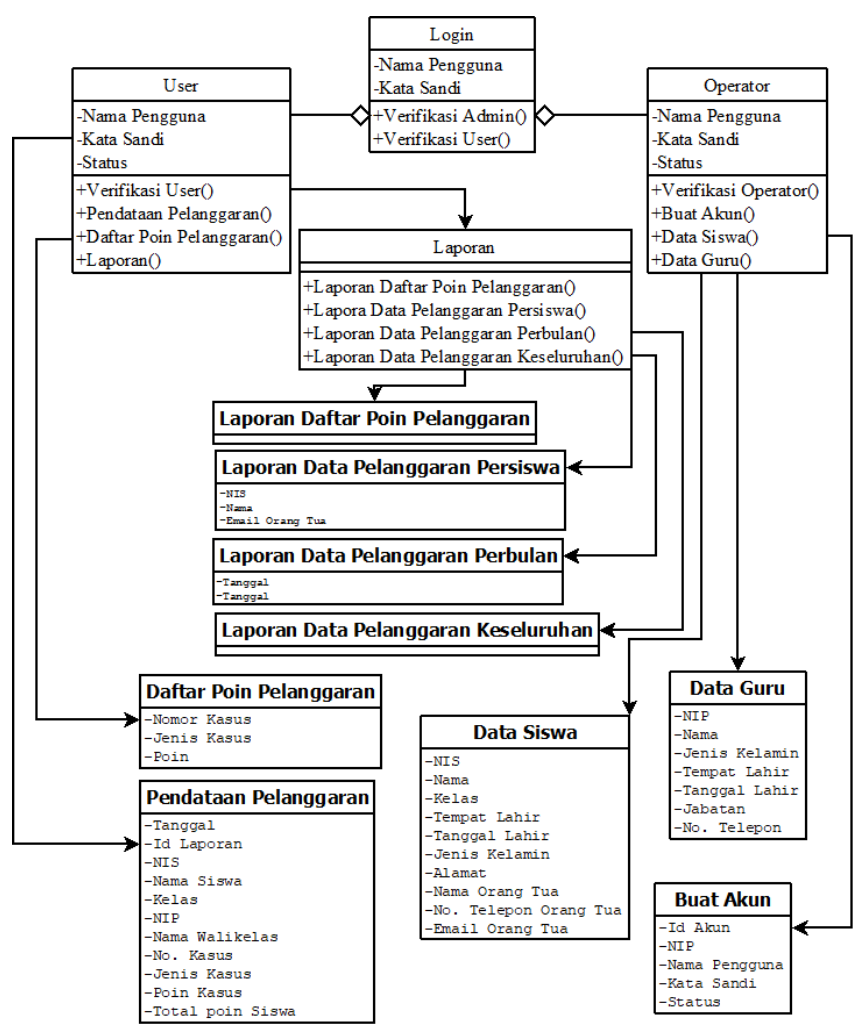

Gambar 4. Class Diagram

Selanjutnya peneliti membuat aplikasi dengan menggunakan IDE Netbeans dan Database MySql. Berikut ini adalah tampilan dari Aplikasi Pendataan Pelanggaran Siswa SMP Negeri 229 Jakarta

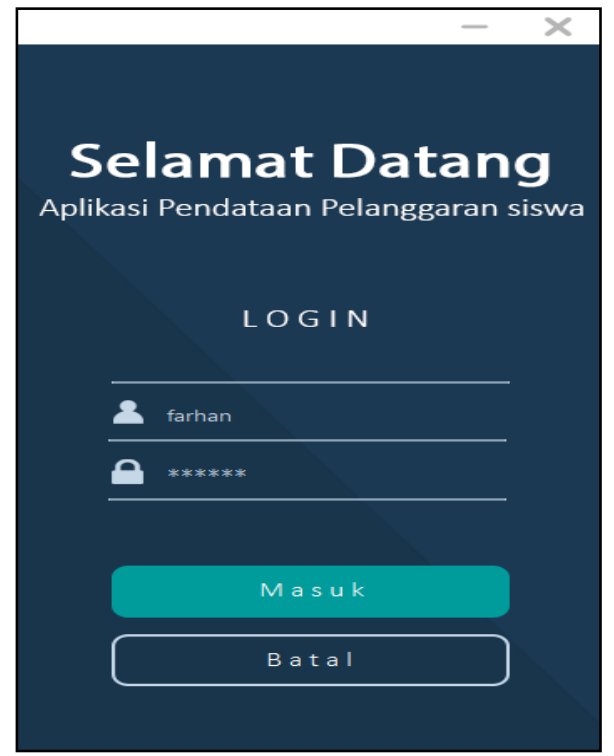

Gambar 5. Tampilan Menu Login

Pada gambar diatas menampilkan menu login saat menjalankan aplikasi, dengan memasukkan username dan password yang sudah didaftarkan di database aplikasi. 

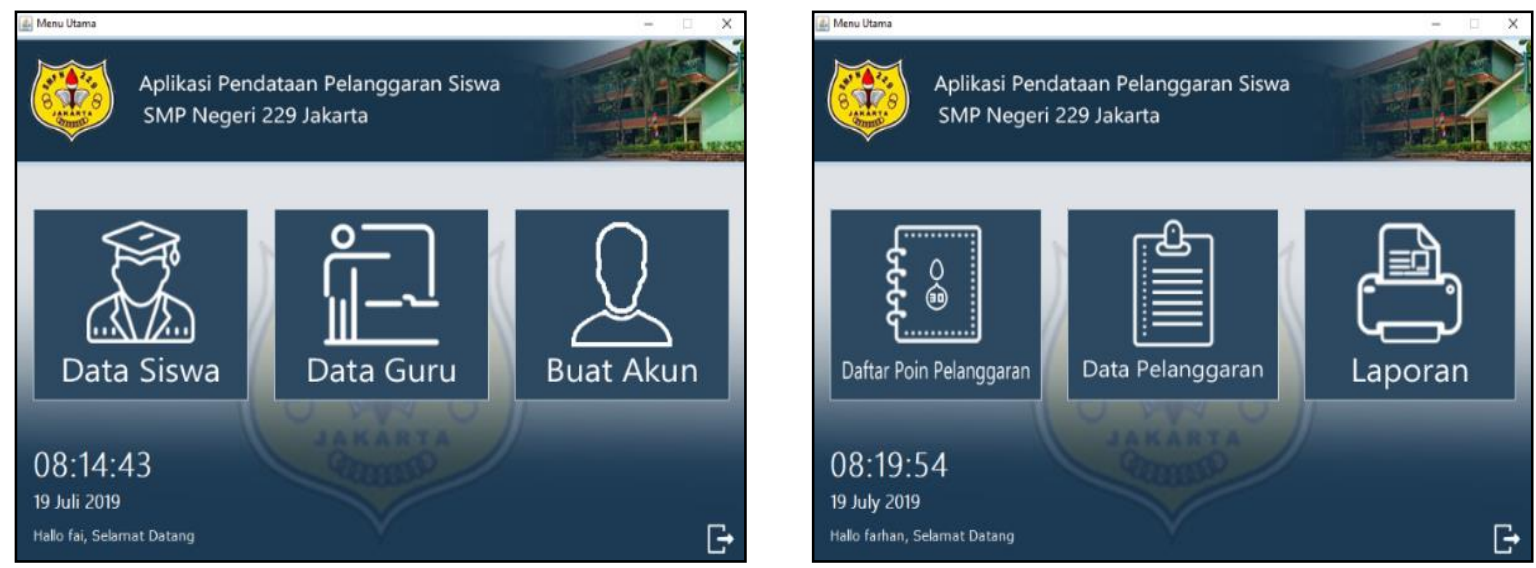

Gambar 6. Tampilan Menu Admin dan User

Gambar diatas menunjukan menu admin dan menu user,untuk menjalankan fungsi yang berbeda-beda sesuai dengan kebutuhan yang di inginkan.

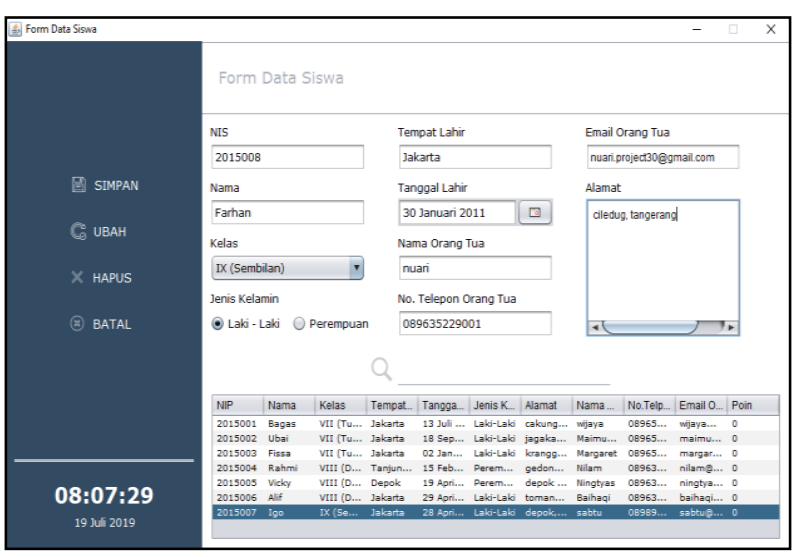

Gambar 7. Tampilan Menu Data Siswa

Pada gambar diatas, untuk input data siswa yang melakukan pelanggaran didalam sekolah yang kemudian akan digunakan untuk pencatatan poin pelanggaran dan report poin pelanggaran.

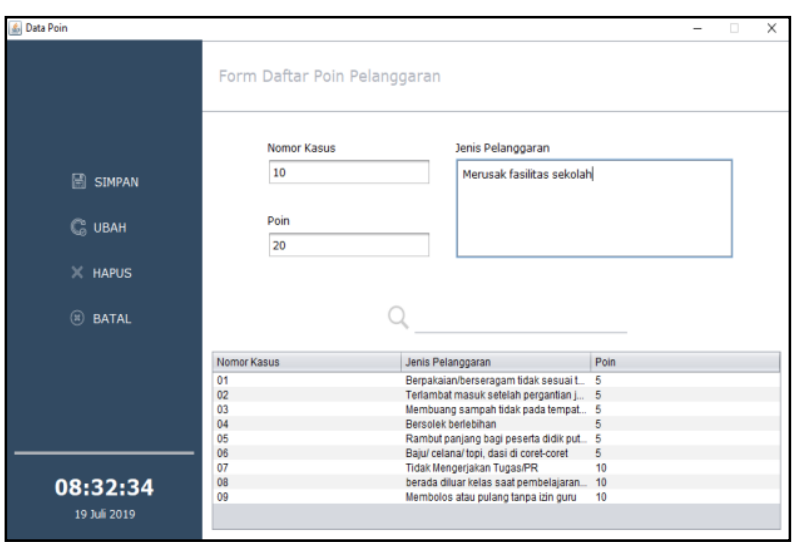

Gambar 8. Tampilan Menu Daftar Poin Pelanggaran

Pada gambar diatas, digunakan untuk mencatat poin pelanggaran yang berlaku pada SMP Negeri 229 Jakarta yang digunakan untuk menentukan poin yang didapat oleh siswa. 


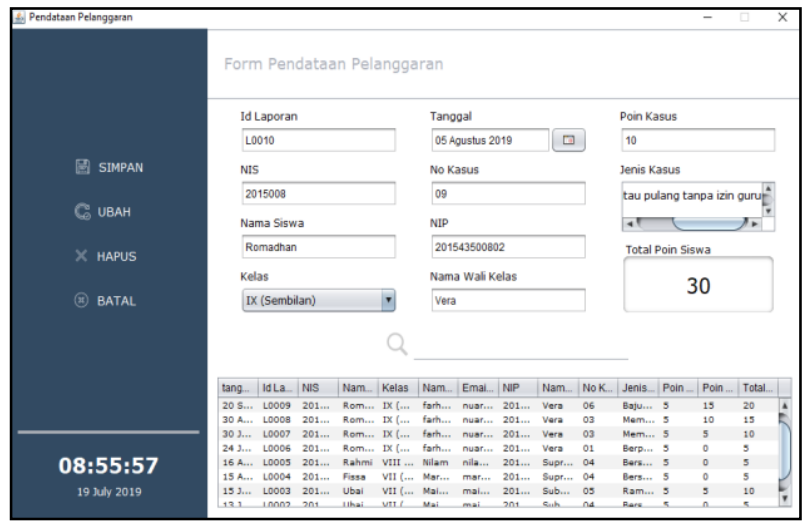

Gambar 9. Tampilan Menu Pendataan Pelanggaran

Pada gambar diatas, digunakan untuk mendata dan memberikan keterangan pelanggaran yang sudah dilakukan oleh siswa tersebut dan langsung mengetahui jumlah poin yang sudah didapat selama sekolah.

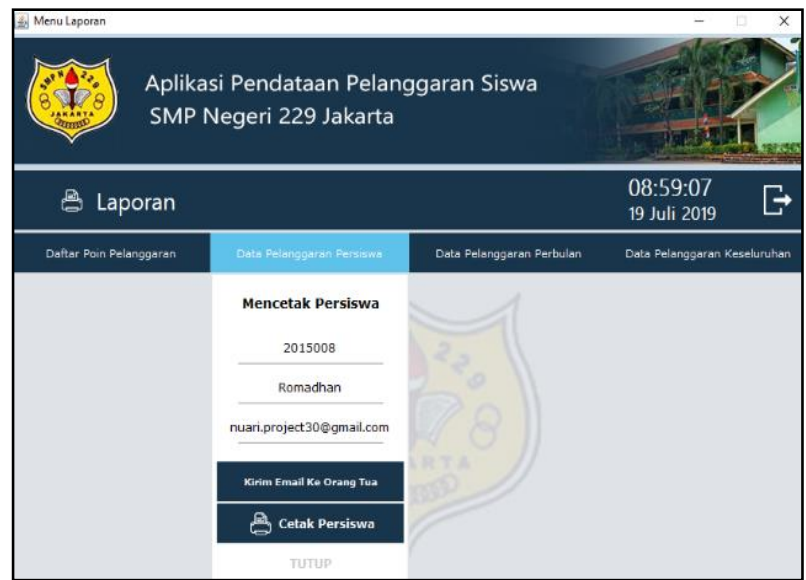

Gambar 10. Tampilan Menu Laporan

Pada gambar diatas, digunakan untuk memilih laporan yang hendak dicetak untuk dijadikan laporan pelanggaran siswa.

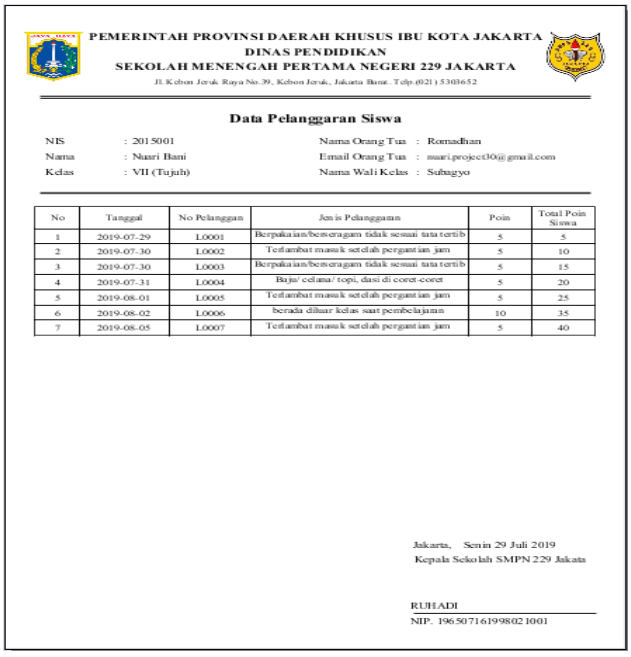

Gambar 11. Tampilan Laporan 
Pada gambar diatas merupakan hasil dari inputan dan proses pendataan pelanggaran siswa dengan aplikasi.

\section{SIMPULAN}

Berdasarkan pembahasan yang telah dilakukan peneliti, maka peneliti mempunyai beberapa kesimpulan simpulan, diantaranya sebagai berikut :

1. Aplikasi Pendataan Pelanggaran Siswa mencatat setiap pelanggaran yang dilakukan oleh siswa tanpa khawatir ke akurasiannya dalam menghitung poin pelanggaran yang telah dilakukan dan Keamanan data pun terjaga tanpa khawatir data hilang, dikarnakan aplikasi ini didukung juga dengan database yang berfungsi untuk menyimpan semua data pelanggaran yang telah di input.

2. Aplikasi Pendataan Pelanggaran Siswa SMP Negeri 229 Jakarta mampu menangani pengolahan data pelanggaran siswa, menjadikan laporan hingga dapat memberikan informasi total poin siswa yang pernah dilakukan oleh siswa.

\section{DAFTAR PUSTAKA}

Sugiyono. (2014). Metode Penelitian Pendidikan Pendekatan Kuantitatif, Kualitatif, dan R\&D. Bandung: Alfabeta Sutabri, T. (2012). Konsep Sistem Informasi. Jurnal Administrasi Pendidikan UPI.

Ahmad Taufiq Hidayatullah \& Fajar Perdana. (2017). Pengembangan sistem informasi bimbingan konseling siswa SMP Negeri 1 Panarukan. Jurnal Pengembangan Teknologi Informasi Dan Ilmu Komputer, 1.

Pascapraharastyan, R. A., Supriyanto, A., \& Sudarmaningtyas, P. (2014). Rancang Bangun Sistem Informasi Manajemen Arsip Rumah Sakit Bedah Surabaya Berbasis Web. Sistem Informasi, 3(1), 72-77

Fajarita, M. A. R. \& L. (2018). Rancang Bangun Sistem Informasi Poin Pelanggaran dan Bimbingan Konseling Pada SMA Az-Zamir. Jurnal Pengembangan Teknologi Informasi Dan Ilmu Komputer, 1.

Syah, Hidayat. (2010). Penelitian Deskriptif. Jakarta: Rajawali.

Ipnuwati, S. (2014). Sistem Pendukung Keputusan Pemberian Sanksi Pelanggaran Kedisiplinan Siswa Pada SMK PGRI I Kendodonng. Jurnal Informatika, Vol. 14, N, 153-167.

Petrisisan W Sudarmadji, A. B. (2017). Pembuatan Aplikasi Pendataan Pada SMA Negeri I Amfoang Utara Kabupaten Kupang. Jurnal Ilmiah FLASH, Volume 3 N, 36-41.

Pressman. (2015). Library Binus. Software Engineering.

Rizki Wahyudi, A. D. A. (2017). Aplikasi Pengolahan Data Pelanggaran Siswa Pada SMK Yayasan Pendidikan Teknologi I Purbalingga Terintegrasi Dengan SMS Gateway. Jurnal Telematik, Vol. 10 No, 62-75. 